10.2478/aucft-2021-0015

\title{
EFFECT ON PHYTOCHEMICAL CONTENT AND MICROBIAL CONTAMINATION OF ACTINIDIA FRUIT AFTER SHOCK COOLING AND STORAGE
}

\author{
- Research paper -
}

\author{
Monika FIGIEL-KROCZYŃSKA, Ireneusz OCHMIAN ${ }^{1}$ \\ Department of Horticulture, West Pomeranian University of Technology Szczecin, Stowackiego 17 \\ Street, 71-434 Szczecin, Poland; \\ Monika Figiel-Kroczyńska; monika.figiel-kroczynska@zut.edu.pl ORCID 0000-0003-4378-4004; \\ Ireneusz Ochmian; iochmian@zut.edu.pl, ORCID 0000-0002-3606-1927,
}

\begin{abstract}
Mini kiwi fruits are tasty and contain valuable nutrients - vitamin, micro end macroelements and polyphenols. The tested cultivars (Sientiabrskaja, Geneva, Issai, Ken's Red) belong to two species of Actinidia (A. arguta and A. kolomikta), which tolerate well the conditions of a temperate climate with negative temperatures in winter. The effect of postharvest shock cooling on fruit quality was investigated after 6 weeks of storage in CA and then after 5 days of shelf life. Shock cooling of fruit after harvest reduced adverse changes in fruit quality after storage in CA cold storage and shelf life. They were firmer, more puncture resistant, and retained more L-ascorbic acid and polyphenols. After 6 weeks of cold storage in CA, eight types of fungi and molds were found that caused the mycotoxins patulin, deoxynivalenol, and zearalenone were found in the fruit of all cultivars. Fruits of the Ken's Red cultivar were the most firm and puncture resistant, the darkest, and contained the most anthocyanins and the least L-ascorbic acid. In contrast, fruits of the cultivar Sientaibrskaja were the least suitable for storage and transport.
\end{abstract}

Key words: Actinidia arguta, Actinidia kolomikta, colour, firmness, polyphenols, CA storage, shelf life

\section{INTRODUCTION}

The genus Actinidia, popularly known as kiwi, is native to China and has about 70 species (Zhang, 2020). The name refers to the New Zealand bird of the same name. The most common species in this genus are Actinidia deliciosa, A. chinensis, $A$. eriantha, A. arguta, A. kolomikta and A. purpurea, (Chesoniene et al., 2003). A. arguta and $A$. kolomikta are perennial, mostly dioecious plants that can also successfully grow in cooler regions because of their excellent freeze tolerance (Latocha, 2017). These species are native to Asia and are mainly cultivated there (Guan et al., 2011). Commercially, the fruits of these species are sold as: kiwi, hardy kiwi, baby kiwi, grape kiwi or mini kiwi (Nishiyama et al., 2004a) (Latocha, 2017). Mini kiwi fruits are small, smooth, and hairless, sweeter and more flavourful than the world's most common kiwi (A. chinensis). This makes them easy to peel and consume whole (Nishiyama et al., 2004a) (Latocha, 2017). They can be eaten raw whole, as

Received: 28.04.2021

Accepted in revised form:11.06.2021

${ }^{1}$ Corresponding authors. E-Mail address: iochmian@zut.edu.pl jam, or made into wine. The fruit is mostly green, but some cultivars with red skin colouring are also available (Latocha, 2017).

Due to its high nutrient and vitamin content, mini kiwi ranks among the top fruits classified as superfoods (Latocha, 2017). Mini kiwi fruits show high antioxidant and anti-inflammatory activity (Drummond, 2013) (Baranowska-Wójcik and Szwajgier, 2019). In China, the leaves and fruits of A. kolomikta are used as a treatment for diabetes (Guan et al., 2011) (Lu et al, 2019). Studies by Zuo et al., 2012, show that Actinidia fruits may be a potential source of natural antioxidants. The antioxidant activity of fruits is associated with three main groups: vitamins, phenols, and carotenoids (Thaipong et al., 2006). Antioxidants sourced from fruits and vegetables are safer and healthier than synthetic ones (Zuo et al., 2012). Actinidia fruits are a valuable source of polyphenols, which are natural antioxidants. The fruits have industrial purposes (Wang, 2013) (Baranowska-Wójcik and Szwajgier, 2019). Polyphenols are potent antioxidants and may exhibit chemo-resistance, 
anti-carcinogenic and anti-inflammatory properties, protect against certain cancers and reduce the risk of diabetes (Jing et al. 2008) (Kamiloglu et al. 2015). Total phenolic content in A. kolomikta and A. arguta fruits is up to $430 \mathrm{mg} 100 \mathrm{~g}-1 \mathrm{FW}$ (BaranowskaWójcik and Szwajgier, 2019). One of the main antioxidants in fruit is $L$-ascorbic acid (vitamin C) (Nishiyama et al., 2004a). Free radicals cause many diseases, including cancer, heart disease, vascular disease, and neurodegenerative diseases (Fiorentino et al., 2009) (Muriel, 2009). Vitamin C is one of the major antioxidants in human body fluids (Kim et al., 2018) (Baranowska-Wójcik and Szwajgier, 2019). The lack of the enzyme gulonolactone oxidase results in humans and great apes being unable to synthesise ascorbic acid (Naidu, 2003). As a result, this vitamin must be supplemented mainly through fruits and vegetables. The vitamin $C$ content of the fruit can be up to $430 \mathrm{mg} / 100 \mathrm{~g} \mathrm{FW}$ (A. arguta), making it one of the richest sources of vitamin $\mathrm{C}$ (Latocha, 2017).

Mini kiwi fruits also contain the highest level of B8 (myo-inositol) - up to $0.982 \mathrm{~g} / 100 \mathrm{~g} \mathrm{FWB}$ and other vitamins od B group among foods. These fruits are the richest source of lutein as well (Nishiyama et al., 2005). Lack of lutein and zeaxanthin can cause blindness associated with cataracts and age-related macular degeneration (AMD) (Abdel-Aal et al., 2013). Fruits are a source of vitamin $E$ (4.6-5.3 $\mathrm{mg} / 100 \mathrm{~g} \mathrm{FW}$ ) and $\beta$-carotene (Nishiyama et al., 2008) (Latocha, 2017) (Zuo et al., 2012). Due to their high dietary fibre content, consumption of $A$. arguta and A. kolomikta fruits normalises intestinal peristalsis and promotes metabolism (Nishiyama et al., 2004b). From among many fruits including the commonly known kiwi fruits (A. deliciosa or A. chinensis), $A$. arguta cultivars are the greatest source of promoting compounds (Latocha, 2017). In recent years, there has been a significant increase in the market demand for high-quality fruit. Therefore,

\section{MATERIAL AND METHODS}

\section{Characteristics of the area of research and plant material}

The experiment was conducted in the Department of Horticulture at West Pomeranian University of Technology in Szczecin. Four cultivars belonging to two species of the Actinidia family were studied in the experiment: Actinidia arguta cultivar Sientiabrskaja and Actinidia kolomitka cultivars Geneva, Issai, and Ken's Red. it is important to assess fruit ripeness and storage shelf life (Gomez et al., 2008). The shelf life of fruit after harvest is determined by appearance (freshness, colour, absence of rot or physiological disorders) and texture (firmness, juiciness, and crispness) (Ayala-Zavala et al., 2004). The method of storage of fruit is very important for its quality and especially for its organoleptic taste characteristics (Barboni et al., 2010). During fruit storage, quantitative losses (weight loss) and qualitative changes occur, which affect the consumer and nutritional value, e.g. decrease in vitamin content, texture, colour, or flavour (Krzysztofik and Łapczyńska-Kordon, 2008). A. arguta fruits have a short shelf life (Latocha et al., 2014) and can be stored under refrigeration (a storage life under refrigeration $0{ }^{\circ} \mathrm{C}, 90-95 \% \mathrm{RH}$ ) for only 2 months. Initial visual assessment of fruit can influence consumer decisions. Characteristics such as colour and firmness mainly determine purchase and consumption. Fruit firmness is a cultivar-specific trait, but it also depends on fruit size (Ochmian and Kozos, 2015). This trait plays a key role during storage and transport. It affects the resistance to mechanical damage. During fruit ripening, its susceptibility to pathogens increases (Valero et al., 2002). Fungal diseases are responsible for the loss of food products (vegetables and fruits) during storage. This is a problem for producers, retailers and consumers. Because due to the mycotoxin presence that poses a danger to human and animal health (Prakash et al., 2015) (Sanzani et al., 2016).

The aim of this experiment is to determine the effect of shock cooling on physico-chemical changes (firmness, color, L-accorbic acid, polyphenols) in mini kiwi fruit after storage period. The type and amount of microbiological contamination and mycotoxin in the fruits were also analyzed.

\section{Fruit storage in cold storage $\mathrm{CA}$}

Fruits of the tested cultivars, selected for uniform size and absence of visible defects, were harvested at of $9-10^{\circ} \mathrm{Brix}$. This is the recommended SSC level for fruit intended for long storage (Latocha et al., 2014).

Both the shock-cooled mini kiwi fruit (temperature drop to $3-4{ }^{\circ} \mathrm{C}$ within 2 hours after picking) and not shock-cooled mini kiwi fruit were then stored in a cold room with a controlled atmosphere $(1.5 ; 1.5)$. Berries were stored for 6 weeks at a temperature of $1.5 \pm 0.25{ }^{\circ} \mathrm{C}$ and relative air humidity of $95 \%$. The experiment was performed in five repetitions, each for $1.25 \mathrm{~kg}$ of berries. 
After six weeks of cold storage in a controlled atmosphere, the fruit was transferred to a room with simulated conditions (shelf life), where it was stored for another five days.

The physical features of fruits (puncture of the skin and firmness), colour, antioxidant activity, and $L$ ascorbic acid were measured on fresh berries. Phenolic samples then were kept frozen $\left(-27{ }^{\circ} \mathrm{C}\right)$ in polyethylene bags $(3 \times 250 \mathrm{~g})$ until analysed.

\section{Colour}

CIE $L^{*} a^{*} b^{*}$ (Color Measurement Committee of the Society of Dyers and Colorists) was measured using a spectrophotometer KonicaMinolta CM-700d. The measured parameters were $L^{*}$ (lightness/darkness), $a^{*}$ (red/green) and $b^{*}$ (yellow/blue). The colour parameters and indices were averaged over 35 measurements.

\section{Firmness}

Firmness and puncture resistance of the berry skin was measured with a FirmTech2 apparatus (BioWorks, USA) on 100 randomly selected berries from three replicates and was expressed as a gramforce causing the berry surface to bend $1 \mathrm{~mm}$. Punctures were made using a stamp with a diameter of $3 \mathrm{~mm}$.

Extraction procedure and identification of phenolic compounds, antioxidant activity

Fruits were then prepared and analyzed according to the methodology of Oszmiański et al. (2018). The fruits were extracted with methanol acidified with $2.0 \%$ formic acid. Separation was conducted twice by incubation for $20 \mathrm{~min}$ under sonication (Sonic 6D, Polsonic, Warsaw, Poland). The sample was shaken several times. Subsequently, the suspension was centrifuged (MPW-251, MPW MED. INSTRUMENTS, Warsaw, Poland) at $19000 \times \mathrm{g}$ for $10 \mathrm{~min}$. Prior to analysis, the supernatant was additionally purified with a Hydrophilic PTFE 0.20 $\mu \mathrm{m}$ membrane (Millex Samplicity Filter, Merck). All extractions were carried out in triplicate.

Analyses were performed according to the methodology of Oszmiański et al. (2018). In kiwiberry fruit extracts, polyphenol identification was executed using an ACQUITY Ultra Performance LC system appointed with a binary solvent manager, a photodiode array detector (Waters Corporation, Milford, MA, USA) and a G2 Q-TOF micro mass spectrometer (Waters, Manchester, UK) equipped with an electrospray ionization (ESI) source operating in both negative and positive modes.

\section{Antioxidant activity}

The ferric reducing antioxidant property (FRAP) was also determined (Benzie and Devaki, 2018). The antioxidant capacity was expressed as millimoles of Trolox per $100 \mathrm{~g}$ distilled water. FRAP assay measurements were carried out on a UV-2401 PC spectrophotometer. $L$-ascorbic acid content was measured with a RQflex 10 requantometer (Merck).

\section{Fruit infestation by moulds and yeasts}

Fruits were collected at the time of harvesting. The research material was placed in sterile plastic containers. The material was subjected to microbiological analysis immediately after harvesting and after cold storage. The analysis of the degree of fruit infestation by fungi (yeasts and moulds) was based on the European standard ISO (Anonymous, 2008). After the cultivation of sporeforming fungal inoculates, they were subjected to taxonomic evaluation using the traditional method of macroscopic observation of colonies and microscopic observation of spores and filaments (Ulbin-Figlewicz et al., 2015). The fungi were identified to the genus level. Colonies were counted using an automatic colony counter (Alchem PCC04). Analyses were performed on three replicates from each sample.

\section{The content of mycotoxins in fruits}

Mycotoxins were determined using HPLC with MS/MS detection (Błajet-Kosicka et al., 2014). The sample was purified on the AflaTest immunological affinity columns from Vicam for aflatoxins and OchraPrep from R-Biopharm Rhóne Ltd for ochratoxin A, according to the procedure specified by the manufacturer. Patulin, deoxynivalenol, T2, HT2 toxin and zearalenone were analyzed by HPLC-MS/MS. The samples were purified on Bond Elut ${ }^{\circ}$ Mycotoxin columns from Varian. Each sample was subjected to 3 repetitions.

\section{Statistical Analysis}

All statistical analyses were performed using Statistica 13.1 (StatSoft Polska, Cracow, Poland). Nonparametric methods (Kruskal-Wallis test) were used if neither the homogeneity of variance nor the normality of distribution was established previously. Statistical significance of the differences between means was determined by testing the homogeneity of variance and normality of distribution, followed by ANOVA with Tukey's post hoc test. The significance was set at $p<0.05$. 


\section{RESULTS AND DISCUSSION}

\section{Firmness and puncture}

The firmness of currently produced kiwi fruits allows them to be stored and transported (White et al., 2005). During long-term storage of A. argute and its hybrid fruits, the strongest changes in fruit characteristics were related to fruit firmness (Latocha et al., 2014) (Figiel-Kroczyńska et. al., 2021). Fruit firmness determines their resistance to mechanical damage (Ochmian and Kozos 2015). Mini kiwi fruits lose firmness during storage and their puncture decreases (Table 1). This may be related to changes in the cell wall and water loss (Jiang, et al., 2016) (Kim et al., 2018). Post-harvest water loss and turgor pressure drop are irreversible, due to the inability of the cell to re-hydrate. The Actinidia cultivars studied were characterised by high variability in initial as well as post-storage firmness. Fresh fruit of Ken's Red cultivar was the most firm, $35 \%$ firmer than the fruit of the Sientiabrskaja cultivar. White et al. (2005) also noted that the small-fruited genotypes of Actinidia are highly variable in terms of final firmness. By applying shock cooling technology to the fruits after harvesting, we prolong their shelf life. Reducing respiration has a positive effect on inhibiting fruit ripening, i.e. starch hydrolysis, chlorophyll degradation, and fruit softening (Lim et al., 2016). Without shock-cooling after shelf life, fruit firmness decreased on average by $23 \%$, while using shockcooled technology fruit firmness decreases by $13.3 \%$ compared to fresh fruit. Latocha et al. (2014) found that fruit firmness decreased by about 25 $30 \%$ after 4 weeks of storage in CA. The rapid loss of firmness becomes apparent when the fruit is removed from cold storage and kept at higher temperatures, making it difficult to transport and sell the fruit (Salvador et al., 2004).

\section{Polyphenolic compounds}

Four subclasses of polyphenols - anthocyanins, phenolic acids, flavonols, and flavan-3-ols - were found among the four Actinidia cultivars studied (Figure 1). The cultivar richest in polyphenols was Sientiabrskaja, followed by Ken's Red, Issai, and Geneva. All four studied cultivars had the most flavan-3-ols. The next rank in terms of content in fruit of the cultivars Sientiabrskaja, Geneva and Issai were phenolic acids > flavonols > anthocyanins. Especially 'Sientiabrskaja' was rich in flavan-3-ols, which made up $57.3 \%$ of all polyphenols in fresh fruit. In the study by Wojdyło et al. (2017), also flavan-3-ols were the major class of polyphenols in Actinidia species but accounted for as much as $96-99 \%$ of all polyphenolic compounds. Next were flavonols $(1-4 \%)>$ phenolic acids (0.4-0.7\%) and anthocyanins (0-0.8\%). 'Ken's Red' fruit also contained a lot of anthocyanins (14.6 $\mathrm{mg} / 100 \mathrm{~g}$, i.e. $31.8 \%$ of all polyphenols). A significant amount of these compounds was also found in fruits of the Geneva cultivar $-3.2 \mathrm{mg} / 100$ g. The content of this group of polyphenols was reflected in the colour of fruits of these two cultivars - they were maroon-red or had red blush.

Table 1. Changes in fruit firmness after storage in a CA for 6 weeks and simulated 5-day shelf life

\begin{tabular}{|c|c|c|c|c|c|c|}
\hline & & Sientiabrskaja & Geneva & Issai & Ken's Red & Mean \\
\hline $\begin{array}{l}\text { Firm } \\
\text { fresh }\end{array}$ & $\begin{array}{l}\text { ss }(\mathrm{G} / \mathrm{mm}) \\
\text { lit - control }\end{array}$ & $126 c^{*}$ & $178 \mathrm{c}$ & $162 \mathrm{~d}$ & $194 d$ & $165 \mathrm{C}$ \\
\hline 离 & Not shock-cooled & $115 b c$ & $167 \mathrm{c}$ & $149 \mathrm{bc}$ & $178 \mathrm{c}$ & 152B \\
\hline 造 & shock-cooled & $121 \mathrm{c}$ & $173 c$ & $153 \mathrm{~cd}$ & $185 \mathrm{~cd}$ & $158 \mathrm{BC}$ \\
\hline 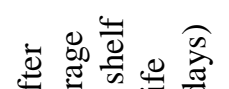 & $\begin{array}{c}\text { not } \\
\text { shock-cooled }\end{array}$ & $87 \mathrm{a}$ & $140 \mathrm{a}$ & $133 a$ & $147 \mathrm{a}$ & $127 \mathrm{~A}$ \\
\hline 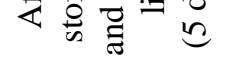 & shock-cooled & $104 b$ & $155 b$ & $145 \mathrm{ab}$ & $166 \mathrm{~b}$ & 143B \\
\hline $\begin{array}{l}\text { Punc } \\
\text { fresh }\end{array}$ & $\begin{array}{l}\text { e (G/mm) } \\
\text { iit - control }\end{array}$ & $79 b$ & $143 d$ & $121 \mathrm{~d}$ & $135 \mathrm{~d}$ & $120 \mathrm{C}$ \\
\hline $\bar{\Xi} \underset{\sigma}{\infty}$ & Not shock-cooled & $75 b$ & $129 \mathrm{bc}$ & $106 \mathrm{c}$ & $127 \mathrm{bc}$ & 109BC \\
\hline$<0$ & shock-cooled & $77 b$ & $135 \mathrm{~cd}$ & $115 \mathrm{~cd}$ & $130 \mathrm{~cd}$ & $114 \mathrm{C}$ \\
\hline 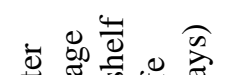 & Not shock-cooled & $55 \mathrm{a}$ & $111 \mathrm{a}$ & $77 \mathrm{a}$ & $103 a$ & 87A \\
\hline 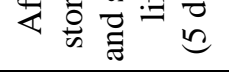 & shock-cooled & $68 \mathrm{ab}$ & $124 b$ & $93 b$ & $117 \mathrm{~b}$ & 101B \\
\hline
\end{tabular}

*Values followed by different letters in columns are significantly different at 5\% level based on Tukey's test 


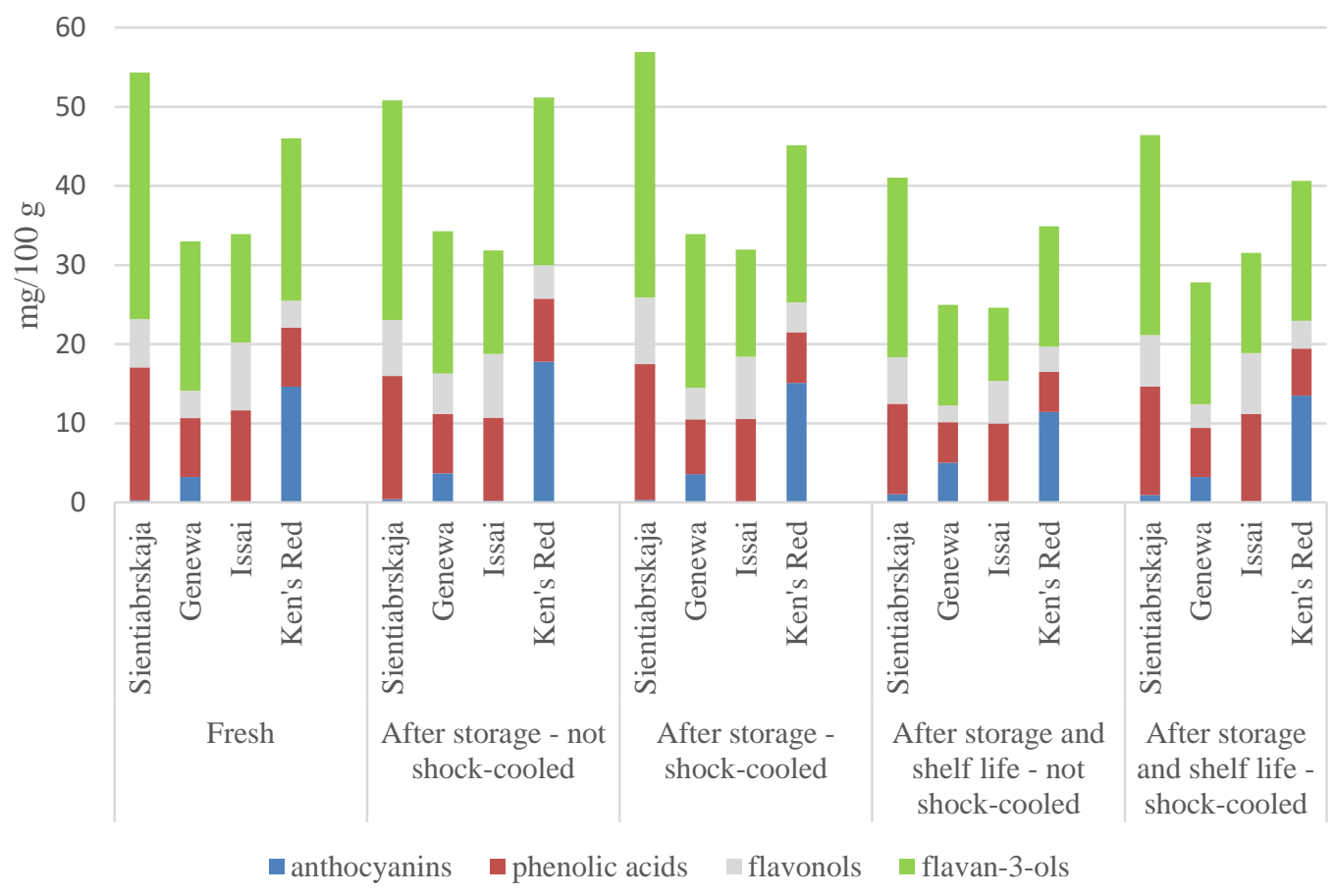

Figure 1. Polyphenols derivative contents in Actinidia fruits after storage in CA for 6 weeks and simulated 5-day shelf life

Anthocyanins, which are mostly located in berries skin, are the reason of colouring them to the red, blue, or purple. They also characterised by high antioxidant activity (Ribera et al., 2010) (Wojdyło et al., 2017). After six weeks of storage, the anthocyanin content increased slightly in these cultivars. This may have been caused by the increased rate of fruit ripening, as evidenced by changes in colour parameters (mainly $a^{*}$ ) and a decrease in fruit firmness. The fruits were more red than fresh fruits.

After 6 weeks of storage, the content of polyphenols in the fruit of all cultivars studied changed. Generally, there was a decrease in the content of these compounds. The storage of fruits in a cold store influences a significant reduction of polyphenols (Ochmian et al., 2020). Only in 'Kens Red' fruits that were not pre-cooled, an increase in polyphenols was observed in all groups, especially in anthocyanins. The use of shock cooling technology for post-harvest fruit reduced polyphenol losses during storage. The highest losses of polyphenols occurred during simulated shelf-life storage, but shock cooling allowed to reduce these losses. Shock cooling of fruit after harvest is a technological process that preserves fruit quality (Kozos et al., 2014).

\section{$L$-ascorbic acid and antioxidant activity}

Mini kiwi is a frut that has a great influence on human body, as it is source of many natural bioactive components, wich has health-promoting effect.

Among them, there are non-enzymatic antioxidants: vitamins and polyphenols. They are the main compounds affecting the antioxidant activity of these fruits (Valko et al., 2006) (Krupa et. al., 2011) (Leontowicz et al., 2016).

Actinidia fruits, especially hybrids such as Issai are the rich source od vitamin $\mathrm{C}$, what is prooved by a lot of scientific publications (Nishiyama et al., 2004a) (Drummond, 2013) (Leontowicz et al., 2016) (Latocha, 2017). In the present study, it was found that the $L$-ascorbic acid content was highest in fresh fruit and averaged $60.5 \mathrm{mg} / 100 \mathrm{~g}$ for the cultivars studied (Table 2). This was within the range obtained by Nishiyama et al. (2004a), (37.3 $184.6 \mathrm{mg} / 100 \mathrm{~g} \mathrm{FW})$. The content decreased on average by as much as $20.1 \%$ after shelf life, for non-shock-cooled fruit. However, shock cooling of fruit after harvest resulted in a slower decrease in $L$ ascorbic acid content by $4.2 \%$ after storage under $\mathrm{CA}$ conditions and another $7 \%$ after shelf life simulated conditions. The results obtained are consistent with those obtained by Tavarini et al. (2008), who also found a decrease in vitamin C in fruit after storage. 
Table 2. Changes in $L$-ascorbic acid content and antioxidant activity of fruit after storage in CA for 6 weeks and simulated 5-day shelf life

\begin{tabular}{|c|c|c|c|c|c|c|}
\hline & & Sientiabrskaja & Geneva & Issai & Ken's Red & Mean \\
\hline \multicolumn{2}{|c|}{$\begin{array}{l}L \text {-ascorbic acid (mg/100) } \\
\text { fresh fruit - control }\end{array}$} & $72.3 b c$ & $55.7 \mathrm{~d}$ & $61.2 \mathrm{c}$ & $52.7 \mathrm{c}$ & $60.5 \mathrm{C}$ \\
\hline \multirow{2}{*}{ 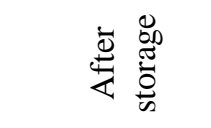 } & Not shock-cooled & $69.0 \mathrm{ab}$ & $52.3 \mathrm{~cd}$ & $54.3 b$ & $45.1 \mathrm{~b}$ & $55.2 \mathrm{~B}$ \\
\hline & shock-cooled & $75.8 \mathrm{c}$ & $50.5 b c$ & $60.0 \mathrm{bc}$ & $43.9 \mathrm{~b}$ & $57.6 B$ \\
\hline \multirow{2}{*}{ 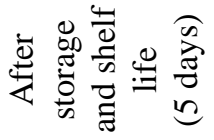 } & Not shock-cooled & $63.6 \mathrm{a}$ & $44.2 \mathrm{a}$ & $47.1 \mathrm{a}$ & $36.3 \mathrm{a}$ & 47.8A \\
\hline & shock-cooled & $68.9 \mathrm{a}$ & 47.9ab & $55.6 \mathrm{~b}$ & $42.4 \mathrm{~b}$ & $53.7 B$ \\
\hline \multicolumn{2}{|c|}{$\begin{array}{l}\text { FRAP }(\mu \mathrm{mol} / \mathrm{T} \mathrm{g}) \\
\text { fresh fruit - control }\end{array}$} & $13.6 \mathrm{a}$ & $19.2 \mathrm{a}$ & $25.0 \mathrm{a}$ & $15.8 \mathrm{a}$ & $18.4 \mathrm{~A}$ \\
\hline \multirow{2}{*}{ 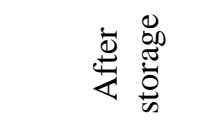 } & Not shock-cooled & $17.3 b$ & $25.8 b$ & $28.3 \mathrm{a}$ & $17.9 \mathrm{a}$ & 22.3B \\
\hline & shock-cooled & $14.8 \mathrm{a}$ & $20.7 \mathrm{a}$ & $28.8 \mathrm{ab}$ & $15.3 \mathrm{a}$ & 19.9AB \\
\hline \multirow{2}{*}{ 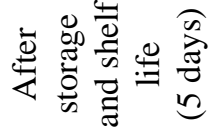 } & Not shock-cooled & $20.1 b$ & $30.1 \mathrm{c}$ & $36.0 \mathrm{c}$ & $22.8 b$ & 27.3C \\
\hline & shock-cooled & $18.9 \mathrm{~b}$ & $19.7 \mathrm{a}$ & $30.4 b$ & $18.1 \mathrm{a}$ & 21.8B \\
\hline
\end{tabular}

*Values followed by different letters in columns are significantly different at 5\% level based on Tukey's test

The FRAP method was used to determine the antioxidant capacity of Actinidia fruit. A high antioxidant capacity of mini kiwi fruits was found. Among the tested cultivars, Sientiabrskaja had the highest antioxidant potential, while Issai had the lowest. Shock-cooled fruit had a significantly higher antioxidant activity, compared to fruit not subjected to this process. After 6 weeks in CA, antioxidant activity decreased by $21 \%$. The highest dynamics of changes were observed after shelf life - after 5 days the fruits lost another $27 \%$ of their free radical binding capacity. A relationship was observed between the method of fruit storage and the decrease in vitamin $\mathrm{C}$ content and FRAP antioxidant capacity. The antioxidant potential measured by the FRAP method depended more on the vitamin $\mathrm{C}$ content than on the phenolic compounds (Wojdyło et al., 2017).

\section{Fruit color}

One of the main parameters affecting consumer acceptance of the fruit is its colour. The colour of kiwi fruit skin and flesh is variable between cultivars (Latocha, 2017). The majority of mini kiwi fruits found to be green, however, some cultivars with red blush and fruits with brown-red color are also present. The color of the studied fruits was determined by the parameter $\mathrm{L}^{*}, \mathrm{a}^{*}$ and $\mathrm{b}^{*}$ (Ochmian et al., 2012).The lightest and greenest fruits were of the Sientiabrskaja cultivar, while the darkest and most reddish-brown fruits were of Ken's Red cultivar (Figiel-Kroczyńska et. al., 2021). This is related to the high content of anthocyanins. Storage of fruit caused fruit darkening, as indicated by the $L^{*}$ parameter. This indicates a progressive ripening of the fruit. Shock cooling inhibits life processes in fruit, which affects the slower change of fruit colour during storage (Fig. 2). There was a change in the colour of the fruit skin during storage. All the fruits were darker in comparison with fresh fruits. 'Sientiabrskaja's' fruits turned dark green. The fruit colour of 'Issai' changed towards yellow and 'Ken's Red' towards dark red. Changes in the value of the $a^{*}$ parameter were most visible in the cultivars Geneva and Ken's Red. The changes that occurred in the colour are a natural phenomenon that takes place during fruit storage. Fruits lose their green colour during storage and this process occurred more slowly when they are properly stored e.g. in a CA cold store (Szpadzik et al., 2021). 


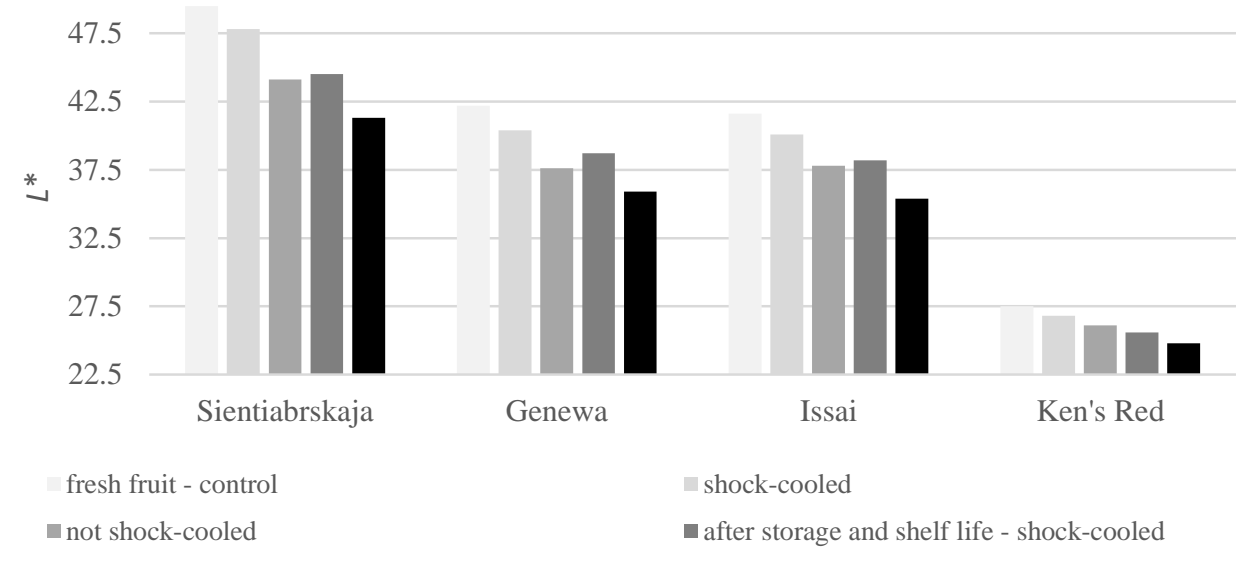

- after storage and shelf life - not shock-cooled

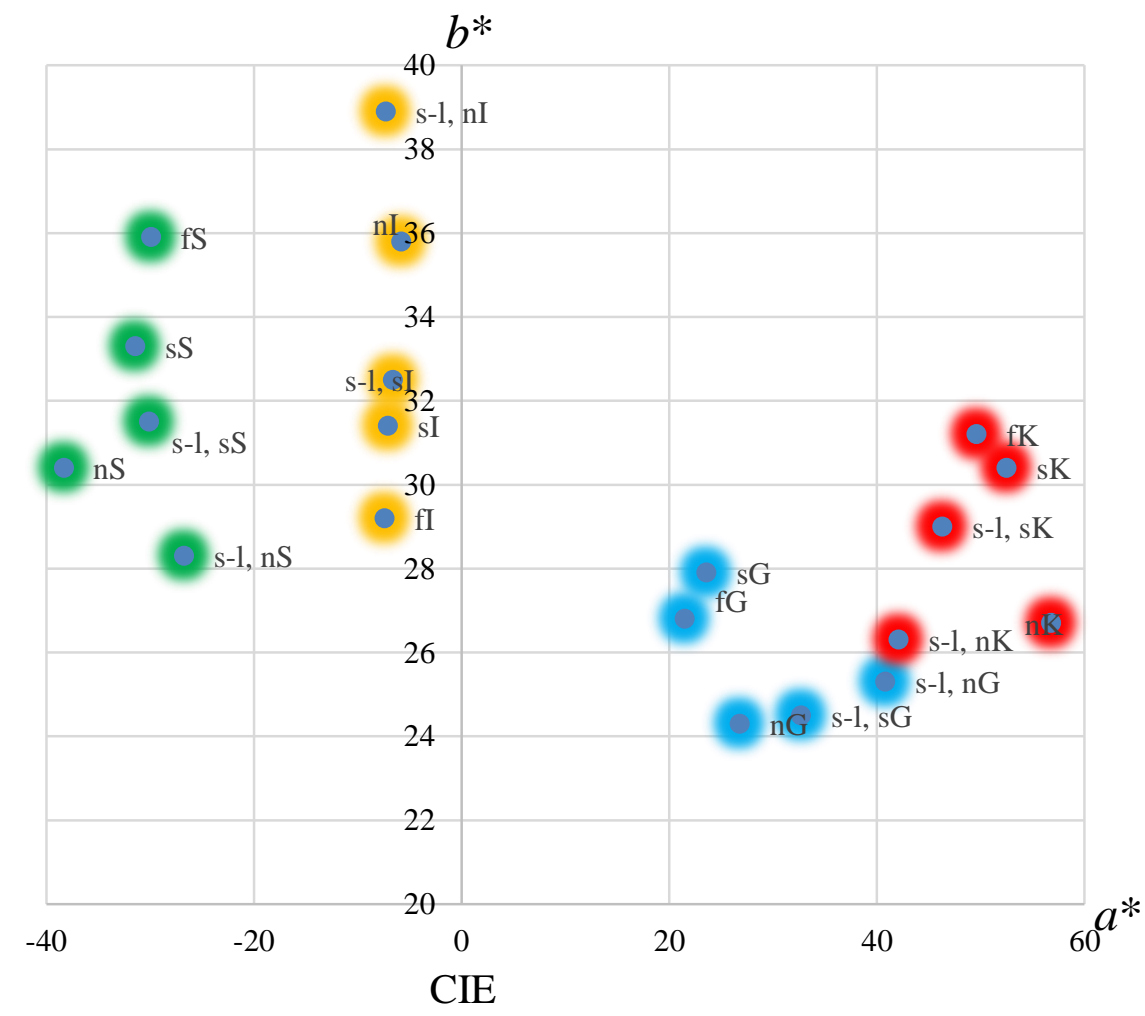

n - not shock-cooled. s - shock-cooled. f - fresh fruit - control. s-1 - shelf life

S - Sientiabrskaja. G - Geneva. I - Issai. K - Ken's Red

Figure 2. Change in fruit colour after CA storage for 6 weeks and simulated 5-day shelf life

\section{Mould and yeast microflora}

The number of yeasts isolated from fruit varied widely (1.6-4.3 $\log 10 \mathrm{CFU} / \mathrm{g}$ ) (Table 3 ). In the cultivars, Sientiabrskaja and Ken's Red the number of yeasts isolated from fruit stored in CA for 6 weeks was lower than from fresh fruit. Storage of fruits for 5 days in shelf life did not affect the number of yeasts to a significant extent. A significant increase was observed only on 'Sientiabrskaja' fruit. On Sientiabrskaja fruit, both fresh and after storage, the highest number of yeast was found (3.5-4.3 $\log 10 \mathrm{CFU} / \mathrm{g})$. The least yeast, but also mould was on Ken's Red fruit - 1.6-2.1 and 1.7-2.0 $\log 10 \mathrm{CFU} / \mathrm{g}$, respectively.

Saprophytic genera (Penicillium, Alternaria, Acremonium, Mucor, Aureobasidium) and phytopathogenic fungi (Bipolaris sp., Botrytis cinera, Phomopsis vaccinni, Phytophtora sp., Rhizoctonia solani, Cladosporium sp., Fusarium $s p$.) are most commonly found on fruit (Bensch et al., 2015). These fungi are commonly found on fruit and in soil (Tournas and Katsoudas, 2005) 
(Kućmierz et al., 2013). Fresh fruits, including Actinidia, are prone to fungal infections, which occur either on the plantation or in cold storage or transport. The fruits contain a lot of simple sugars and organic acids, which is a good breeding ground for yeasts and moulds. Infections adversely affect the visual appearance of the fruit and its composition, as well as its nutritional value.

Fungi belonging to eight different genera (Cladosporium, Fusarium, Penicillium,
Acremonium, Alternaria, Aureobasidium, Bipolaris and Mucor) were isolated from fresh fruit and only five fungal genera from stored fruit. Although more fungal genera were found on fresh fruit, the vast majority belonged to one dominant genus, i.e. Cladosporium (Table 3). On the fruit of all minikiwi cultivars, fresh and stored, they amounted to $38-93 \%$ of all identified fungi. After storage, fungi of the genera Aureobasidium and Fusarium were found to increase in abundance (Table 4).

Table 3. Impact of the storage of Actinidia fruit on the amount of yeast and mould

\begin{tabular}{|c|c|c|c|c|c|c|}
\hline & & Sientiabrskaja & Geneva & Issai & Ken's Red & Mean \\
\hline \multirow{2}{*}{ 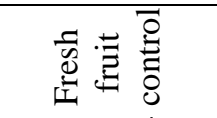 } & Yeast $\log _{10} \mathrm{CFU} / \mathrm{g}$ & $4.0 \mathrm{c} / \mathrm{B}^{\mathrm{a}}$ & $3.9 \mathrm{c} / \mathrm{A}$ & $2.7 \mathrm{~b} / \mathrm{A}$ & $2.1 \mathrm{a} / \mathrm{B}$ & $3.2 \mathrm{~A}$ \\
\hline & Mould $\log _{10} \mathrm{CFU} / \mathrm{g}$ & $3.3 \mathrm{~b} / \mathrm{B}$ & $3.5 \mathrm{~b} / \mathrm{A}$ & $3.3 \mathrm{~b} / \mathrm{A}$ & $1.9 \mathrm{a} / \mathrm{AB}$ & $3.0 \mathrm{~A}$ \\
\hline \multirow{2}{*}{ 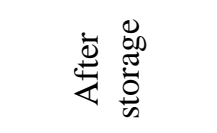 } & Yeast $\log _{10} \mathrm{CFU} / \mathrm{g}$ & $3.5 \mathrm{c} / \mathrm{A}$ & $3.7 \mathrm{c} / \mathrm{A}$ & $2.9 \mathrm{~b} / \mathrm{AB}$ & $1.7 \mathbf{a} / \mathbf{A}$ & 3.0A \\
\hline & Mould $\log _{10} \mathrm{CFU} / \mathrm{g}$ & $2.7 \mathrm{~b} / \mathrm{A}$ & $3.5 \mathrm{c} / \mathrm{A}$ & $3.0 \mathrm{~b} / \mathrm{A}$ & $1.7 \mathrm{a} / \mathrm{A}$ & $2.7 \mathrm{~A}$ \\
\hline \multirow{2}{*}{ 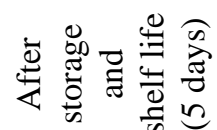 } & Yeast $\log _{10} \mathrm{CFU} / \mathrm{g}$ & $4.3 \mathrm{~d} / \mathrm{B}$ & $3.9 \mathrm{c} / \mathrm{A}$ & $3.2 \mathrm{~b} / \mathrm{B}$ & $1.6 \mathrm{a} / \mathrm{A}$ & 3.3A \\
\hline & Mould $\log _{10} \mathrm{CFU} / \mathrm{g}$ & $2.9 \mathrm{~b} / \mathrm{AB}$ & $3.8 \mathrm{c} / \mathrm{B}$ & $3.2 \mathrm{~b} / \mathrm{A}$ & $2.0 \mathrm{a} / \mathrm{B}$ & $3.0 \mathrm{~A}$ \\
\hline
\end{tabular}

${ }^{a}$ Values followed by the same letter, within the same column, were not significantly different $(\mathrm{p}<0.05)$ according to the t-Tukey test; lower case letters in a line, capitals in column

Table 4. Impact of the storage of Actinidia fruit on the composition and variety of fungi as well as the presence of mycotoxins in fruit

\begin{tabular}{|c|c|c|c|c|c|c|c|c|c|}
\hline & & & entiabrskaja & & Geneva & & Issai & & Ken's Red \\
\hline \multirow{10}{*}{ 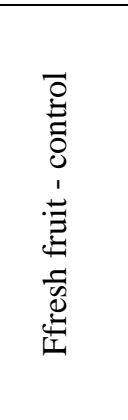 } & \multirow{7}{*}{$\begin{array}{l}\text { Percentage }(\%) \\
\text { of fungi genus }\end{array}$} & 70 & Cladosporium & 67 & Cladosporium & 79 & Cladosporium & 89 & Cladosporium \\
\hline & & 18 & Fusarium & 15 & Aureobasidium & 10 & Fusarium & 6 & Alternaria \\
\hline & & 5 & Penicillium & 8 & Penicillium & 4 & Penicillium & 3 & Bipolaris \\
\hline & & 3 & Alternaria & 7 & Fusarium & 3 & Alternaria & 2 & Acremonium \\
\hline & & 2 & Acremonium & 2 & Alternaria & 2 & Acremonium & & \\
\hline & & 1 & Bipolaris & 1 & Bipolaris & 1 & Bipolaris & & \\
\hline & & 1 & Mucor & & & 1 & Eurotium & & \\
\hline & \multirow{3}{*}{$\begin{array}{c}\text { Mycotoxins } \\
\mu \mathrm{g} / \mathrm{kg}\end{array}$} & 3.11 & PAT & 1.28 & PAT & 1.55 & DON & & \\
\hline & & 1.13 & DON & 0.79 & DON & 0.73 & PAT & & \\
\hline & & 0.13 & $\mathrm{ZEN}^{\mathrm{b}}$ & & & & & & \\
\hline \multirow{7}{*}{ 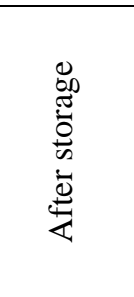 } & \multirow{5}{*}{$\begin{array}{l}\text { Percentage }(\%) \\
\text { of fungi genus }\end{array}$} & 38 & Cladosporium & 52 & Cladosporium & 46 & Cladosporium & 93 & Cladosporium \\
\hline & & 28 & Aureobasidium & 44 & Fusarium & 38 & Fusarium & 7 & Penicillium \\
\hline & & 16 & Alternaria & 4 & Penicillium & 9 & Penicillium & & \\
\hline & & 13 & Fusarium & & & 7 & Alternaria & & \\
\hline & & 5 & Penicillium & & & & & & \\
\hline & Mycotoxins & 0.55 & PAT & 0.64 & PAT & 0.22 & DON & 0.53 & PAT \\
\hline & $\mu \mathrm{g} / \mathrm{kg}$ & 0.09 & $\mathrm{ZEN}^{\mathrm{b}}$ & 0.23 & DON & & & & \\
\hline \multirow{7}{*}{ 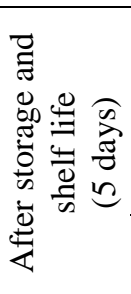 } & \multirow{5}{*}{$\begin{array}{l}\text { Percentage of } \\
\text { fungi genus }\end{array}$} & 58 & Cladosporium & 81 & Cladosporium & 77 & Cladosporium & 79 & Cladosporium \\
\hline & & 19 & Aureobasidium & 10 & Penicillium & 9 & Fusarium & 14 & Penicillium \\
\hline & & 11 & Fusarium & 7 & Fusarium & 9 & Penicillium & 7 & Fusarium \\
\hline & & 9 & Penicillium & 2 & Alternaria & 3 & Alternaria & & \\
\hline & & 3 & Alternaria & & & 2 & Aureobasidium & & \\
\hline & Mycotoxins & 1.05 & PAT & 0.44 & PAT & 1.20 & PAT & 0.88 & PAT \\
\hline & $\mu \mathrm{g} / \mathrm{kg}$ & 0.17 & $\mathrm{ZEN}^{\mathrm{b}}$ & 0.43 & DON & 0.17 & DON & & \\
\hline
\end{tabular}

${ }^{a}$ Values followed by the same letter, within the same column, were not significantly different $(\mathrm{p}<0.05)$ according to tTukey test; ' Deoxynivalenol - DON, Patulin - PAT, Zearalenone - ZEN 
In samples where Fusarium fungi were isolated, Deoxynivalenol, a mycotoxin of the genus Fusarium, was also found $(0.17-1.55 \mu \mathrm{g} / \mathrm{kg}$ in fresh and stored fruit) (Table 4). Zearalenone, which is a toxic secondary metabolite also from Fusarium fungi, was detected only in fresh Sientiabrskaja fruit $(0.13 \mu \mathrm{g} / \mathrm{kg})$ after storage $(0.09-0.17 \mu \mathrm{g} / \mathrm{kg})$. Patulin $(0.44-3.11 \mu \mathrm{g} / \mathrm{kg})$, a secondary metabolite of some mould species, including the genus Penicillium, was also detected in the fruit. Patulin is a toxin with mutagenic, teratogenic, and possibly carcinogenic properties. The World Health Organisation (WHO) and the European Commission have set a maximum concentration limit for patulin in apple juice of 50 $\mu \mathrm{g} / \mathrm{kg}$ (EC, 2006). 6 weeks storage of fruit in CA at a temperature of $1.5^{\circ} \mathrm{C} \pm 0.25^{\circ} \mathrm{C}$, did not eliminate

\section{CONCLUSIONS}

The physicochemical and health-promoting properties deteriorated during the storage of the of mini kiwi studied cultivars A. arguta and A. kolomikta: firmness, puncture resistance, $L$ ascorbic acid level, polyphenol content, and antioxidant capacity (FRAP).

The results of the study show that shock cooling of mini kiwifruit improves their storage quality and extends shelf life.

Among the four cultivars studied, the fruit of Ken's Red was the most firm and puncture-resistant, the
Fusarium. This resulted in the presence in the fruit of Deoxynivalenol and Zearalenone. Chilling circumstances are not efficient in eliminating toxinproducing fungi (Alshannaq and $\mathrm{yu}, 2017$ ) (Tournas and Katsoudas, 2005). Ochratoxin A, T2 HT2 toxin, Aflatoxins (BI, B2, GI, G2) were not identified in fresh and stored fruit samples. The presence of mycotoxins in the tested fruits was found at a low level. This could be influenced by yeasts and fungi e.g. of the genus Aureobasidium. They can degrade mycotoxins through microbial pathways (Zhu, R. et al., 2015). They show strong antagonism towards moulds contaminating fruit and can provide effective bioprotection (Chi, Z. et al., 2009).

darkest, and had the most anthocyanins, while Lascorbic acid was the least. The fruits of the Sientaibrskaja cultivar were the least suitable for storage and transport.

To prolong the storage time and preserve the healthpromoting properties of $\mathrm{A}$. arguta and $\mathrm{A}$. kolomikta fruit, the method of fruit shock cooling after harvesting should be used.

It is very important to test fruits for mycotoxins, especially after storage, before they reach consumers. After 6 weeks of cold storage in CA, the mycotoxins Patulin, Deoxynivalenol, or Zearalenone were found in the fruit of all cultivars.

\section{Funding}

This research was supported by the West Pomeranian University of Technology of grants nr 518-07-014-3171$03 / 18$.

\section{Conflict of interest}

The authors declare that they have no known competing financial interests or personal relationships that could have appeared to influence the work reported in this paper.

\section{Compliance with ethics requirements}

This article does not contain any studies with human or animal subjects.

\section{Declaration of competing interest}

The authors declare that they have no known competing financial interests or personal relationships that could have appeared to influence the work reported in this paper.

\section{REFERENCES}

1. Abdel-Aal, E. S. M., Akhtar, H., Zaheer, K. \& Ali, R. (2013). Dietary sources of lutein and zeaxanthin carotenoids and their role in eye health. Nutrients, 5(4), 1169-1185. DOI: 10.3390/nu5041169.

2. Alshannaq, A. \& Yu, J.-H. (2017). Occurrence, toxicity, and analysis of major mycotoxins in food. Int. J. Environ. Res. Public Health. 14, 632. https://doi.org/10.3390/ijerph14060632.

3. Anonymous. (2008). Microbiology of food and animal feeding stuffs - Horizontal method for the enumeration of yeasts and moulds. Part 1: Colony count technique in products with water activity greater than 0.95. ISO 21527-1:2008. 1st edn (International Organization for Standardization, Geneva, Switzerland, 2008). 
4. Ayala-Zavala, J. F., Wang, S. Y., Wang, C. Y. \& González-Aguilar, G. A. (2004). Effect of storage temperatures on antioxidant capacity and aroma compounds in strawberry fruit. LWT-Food Science and Technology, 37(7), 687-695. DOI: 10.1016/j.lwt.2004.03.002

5. Baranowska-Wójcik, E. \& Szwajgier, D. (2019). Characteristics and pro-health properties of mini kiwi (Actinidia arguta). Hortic. Environ. Biotechnol. 60(2), 217-225. DOI: 10.1007/s13580-018-0107-y.

6. Barboni, T., Cannac, M. \& Chiaramonti, N. (2010). Effect of cold storage and ozone treatment on physicochemical parameters, soluble sugars and organic acids in Actinidia deliciosa. Food chemistry, 121(4), 946-951. DOI: 10.1016/j.foodchem.2010.01.024.

7. Bensch, K., Groenewald, J. Z., Braun, U., Dijksterhuis, J., de Jesús Yáñez-Morales, M. \& Crous, P. W. (2015). Common but different: The expanding realm of Cladosporium open access. Stud. Mycol. 82, 2374 (2015). DOI: 10.1016/j.simyco.2015.10.001.

8. Benzie, I.F. \& Devaki, M. (2018). The ferric reducing/antioxidant power (FRAP) assay for non-enzymatic antioxidant capacity: Concepts, procedures, limitations and applications. Measurement of antioxidant activity \& capacity: recent trends and applications Wiley, New York, 77-106. DOI:10.1002/9781119135388.

9. Błajet-Kosicka, A., Twarużek, M., Kosicki, R., Sibiorowska, E. \& Grajewski, J. (2014). Co-occurrence and evaluation of mycotoxins in organic and conventional rye grain and products. Food Control, 38, 6166. DOI: 10.1016/j.foodcont.2013.10.003.

10. Chesoniene, L., Daubaras, R. \& Viskelis, P. (2003). Biochemical composition of berries of some kolomikta kiwi (Actinidia kolomikta) cultivars and detection of harvest maturity. In XI Eucarpia Symposium on Fruit Breeding and Genetics 663 (pp. 305-308). DOI: 10.17660/ActaHortic.2004.663.50.

11. Chi, Z., Wang, F., Chi, Z., Yue, L., Liu, G. \& Zhang, T. (2009). Bioproducts from Aureobasidium pullulans, a biotechnologically important yeast. Appl. Microbiol. Biotechnol. 82, 793-804 (2009). DOI 10.1007/s00253-009-1882-2.

12. Drummond, L. (2013). The composition and nutritional value of kiwi fruit. Adv. Food Nutr. Res. 68, $33-$ 57. DOI: 10.1016/B978-0-12-394294-4.00003-1.

13. European Commission (2006). Commission Regulation (EC) No 1881/2006 setting maximum levels for certain contaminants in foodstuffs.

14. Fiorentino, A., D’Abrosca, B., Pacifico, S., Mastellone, C., Scognamiglio, M. \& Monaco, P. (2009). Identification and assessment of antioxidant capacity of phytochemicals from kiwi fruits. Journal of agricultural and food chemistry, 57(10), 4148-4155. DOI: 10.1021/jf900210z.

15. Gomez, A. H., Wang, J., Hu, G. \& Pereira, A. G. (2008). Monitoring storage shelf life of tomato using electronic nose technique. Journal of Food Engineering, 85(4), 625-631. DOI: 10.1016/j.jfoodeng.2007.06.039.

16. Guan, D., Zhang, Z., Yang, Y., Xing, G. \& Liu, J. (2011). Immunomodulatory activity of polysaccharide from the roots of Actinidia kolomikta on macrophages. Int. J. Biol. 3(2), 3. DOI:10.5539/ijb.v3n2p3.

17. Jiang, H., Sun, Z., Jia, R., Wang, X. \& Huang, J. (2016). Effect of chitosan as an antifungal and preservative agent on postharvest blueberry. J. Food Qual. 39(5), 516-523. DOI: 10.1111/jfq.12211.

18. Jing, P., Bomser, J. A., Schwartz, S. J., He, J., Magnuson, B. A. \& Giusti, M. M. (2008). Structurefunction relationships of anthocyanins from various anthocyanin-rich extracts on the inhibition of colon cancer cell growth. Journal of agricultural and food chemistry, 56(20), 9391-9398.

19. Kamiloglu, S., Capanoglu, E., Grootaert, C. \& Van Camp, J. (2015). Anthocyanin absorption and metabolism by human intestinal Caco-2 cells-A review. Int J Mol Sci 16(9), 21555-21574. DOI: 10.3390/ijms 160921555.

20. Kim, A. N., Kim, H. J., Chun, J., Heo, H. J., Kerr, W. L. \& Choi, S. G. (2018). Degradation kinetics of phenolic content and antioxidant activity of hardy kiwifruit (Actinidia arguta) puree at different storage temperatures. LWT, 89, 535-541. DOI: 10.1016/j.1wt.2017.11.036.

21. Kozos, K., Ochmian, I. \& Chełpiński, P. (2014). The effects of rapid chilling and storage conditions on the quality of Brigitta Blue cultivar highbush blueberries (Vaccinium corymbosum L.). Folia Horticulturae, 26(2), 147-153. DOI: 10.1515/fhort-2015-000.

22. Figiel-Kroczyńska, M., Ochmian, I., Lachowicz, S., Krupa-Małkiewicz, M., Wróbel, J., \& Gamrat, R. (2021). Actinidia (mini kiwi) fruit quality in relation to summer cutting. Agronomy, 11(5), 964. DOI:10.3390/agronomy11050964

23. Krupa, T., Latocha, P. \& Liwińska, A. (2011). Changes of physicochemical quality, phenolics and vitamin $\mathrm{C}$ content in hardy kiwifruit (Actinidia arguta and its hybrid) during storage. Scientia Horticulturae, 130(2), 410-417. DOI: 10.1016/j.scienta.2011.06.044. 
24. Krzysztofik, B. \& Łapczyńska-Kordon, B. (2008). Wpływ sposobów i czasu przechowywania na wybrane cechy sensoryczne jabłek. Inżynieria Rolnicza, 12, 121-128.

25. Kućmierz, J., Nawrocki, J. \& Sojka, A. (2013). Fungi isolated from diseased early green fruits and fruits of blueberry (Vaccinium corymbosum L.). Prog. Plant Prot. 53, 779-784.

26. Latocha, P. (2017). The Nutritional and Health Benefits of Kiwiberry (Actinidia arguta) - a Review. Plant Foods Hum. Nutr. 72, 325-334. DOI: 10.1007/s11130-017-0637-y.

27. Latocha, P., Krupa, T., Jankowski, P. \& Radzanowska, J. (2014). Changes in postharvest physicochemical and sensory characteristics of hardy kiwifruit (Actinidia arguta and its hybrid) after cold storage under normal versus controlled atmosphere. Postharvest biology and technology, 88, 21-33. DOI: 10.1016/j.postharvbio.2013.09.005.

28. Leontowicz, H., Leontowicz, M., Latocha, P., Jesion, I., Park, Y. S., Katrich, E., Barasch, D., Nemirovski. A. \& Gorinstein, S. (2016). Bioactivity and nutritional properties of hardy kiwi fruit Actinidia arguta in comparison with Actinidia deliciosa 'Hayward' and Actinidia eriantha 'Bidan'. Food Chem. 196, 281 291. DOI: 10.1016/j.foodchem.2015.08.127.

29. Lim, S., Han, S. H., Kim, J., Lee, H. J., Lee, J. G. \& Lee, E. J. (2016). Inhibition of hardy kiwifruit (Actinidia aruguta) ripening by 1-methylcyclopropene during cold storage and anticancer properties of the fruit extract. Food chemistry, 190, 150-157. DOI: 10.1016/j.foodchem.2015.05.085.

30. Lu, J., Jin, Y., Liu, G., Zhu, N., Gui, M., Yu, A. \& Li, X. (2010). Flavonoids from the leaves of Actinidia kolomikta. Chem. Nat. Compd, 46(2), 205-208.

31. Muriel, P. (2009). Role of free radicals in liver diseases. Hepatology international, 3(4), 526-536. DOI $10.1007 / \mathrm{s} 12072-009-9158-6$.

32. Naidu, K. A. (2003). Vitamin C in human health and disease is still a mystery? An overview. Nutrition journal, 2(1), 1-10.

33. Nishiyama, I., Fukuda, T. \& Oota, T. (2004b). Varietal differences in actinidin concentration and protease activity in the fruit juice of Actinidia arguta and Actinidia rufa. J. Jpn. Soc. Hortic. Sci. 73, 157-162. DOI: $10.2503 /$ jjshs.73.157.

34. Nishiyama, I., Fukuda, T. \& Oota, T. (2005). Genotypic differences in chlorophyll, lutein, and $\beta$-carotene contents in the fruits of actinidia species. J. Agric. Food. Chem. 53, 6403-6407. DOI: 10.1021/jf050785y.

35. Nishiyama, I., Fukuda, T., Shimohashi, A. \& Oota, T. (2008). Sugar and organic acid composition in the fruit juice of different Actinidia varieties. Food. Sci. Technol. Res. 14(1), 67-73. DOI: 10.3136/fstr.14.67.

36. Nishiyama, I., Yamashita, Y., Yamanaka, M., Shimohashi, A., Fukuda, T. \& Oota, T. (2004a). Varietal difference in vitamin $\mathrm{C}$ content in the fruit of kiwi fruit and other Actinidia species. J. Agric. Food Chem. 52(17), 5472-5475. DOI: 10.1021/jf049398z.

37. Ochmian, I., Figiel-Kroczyńska, M. \& Lachowicz, S. (2020). The Quality of Freeze-Dried and Rehydrated Blueberries Depending on their Size and Preparation for Freeze-Drying. Acta Univ. Cibiniensis, Ser. E: FoodTechnol.24(1), 61-78. DOI: 10.2478/aucft-2020-0006.

38. Ochmian, I. \& Kozos, K. (2015). Influence of foliar fertilization with calcium fertilizers on the firmness and chemical composition of two high bush blueberry cultivars. J. Elem. 20(1), 185-201. DOI: 10.5601/jelem.2014.19.4.782.

39. Ochmian, I., Grajkowski, J. \& Smolik, M., 2012. Comparison of some morphological features, quality and chemical content of four cultivars of chokeberry fruits (Aronia melanocarpa). Not. Bot. Horti. Agrobot. Cluj Napoca, 40(1), 253-260.

40. Oszmiański, J., Lachowicz, S., Gławdel, E., Cebulak, T. \& Ochmian, I. (2018). Determination of photochemical composition and antioxidant capacity of 22 old apple cultivars grown in Poland. Eur. Food Res. Technol. 244(4), 647-662. DOI: 10.1007/s00217-017-2989-9.

41. Prakash, B., Kedia, A., Mishra, P. K. \& Dubey, N. K. (2015). Plant essential oils as food preservatives to control moulds, mycotoxin contamination and oxidative deterioration of agri-food commoditiesPotentials and challenges. Food Control, 47, 381-391. DOI: 10.1016/j.foodcont.2014.07.023

42. Ribera, A. E., Reyes-Diaz, M., Alberdi, M., Zuñiga, G. E. \& Mora, M. L. (2010). Antioxidant compounds in skin and pulp of fruits change among genotypes and maturity stages in highbush blueberry (Vaccinium corymbosum L.) grown in southern Chile. J. Soil Sci. Plant Nutr. 10(4), 509-536. DOI: 10.4067/S071895162010000200010.

43. Salvador, A., Arnal, L., Monterde, A. \& Cuquerella, J. (2004). Reduction of chilling injury symptoms in persimmon fruit cv.'Rojo Brillante'by 1-MCP. Postharvest Biology and Technology, 33(3), 285-291. DOI: 10.1016/j.postharvbio.2004.03.005. 
44. Sanzani, S. M., Reverberi, M. \& Geisen, R. (2016). Mycotoxins in harvested fruits and vegetables: Insights in producing fungi, biological role, conducive conditions, and tools to manage postharvest contamination. Postharvest Biology and Technology, 122, 95-105. DOI: 10.1016/j.postharvbio.2016.07.003.

45. Szpadzik, E., Zaraś-Januszkiewicz, E. \& Krupa, T. (2021). Storage Quality Characteristic of Two Minikiwi Fruit (Actinidia arguta (Siebold \& Zucc.) Planch. ex Miq.) Cultivars: 'Ananasnaya'and 'Bingo'-A New One Selected in Poland. Agronomy, 11(1), 134. DOI: 10.3390/agronomy11010134.

46. Tavarini, S., Degl'Innocenti, E., Remorini, D., Massai, R. \& Guidi, L. (2008). Antioxidant capacity, ascorbic acid, total phenols and carotenoids changes during harvest and after storage of Hayward kiwifruit. Food Chem. 107(1), 282-288. DOI: 10.1016/j.foodchem.2007.08.015.

47. Thaipong, K., Boonprakob, U., Crosby, K., Cisneros-Zevallos, L. \& Byrne, D. H. (2006). Comparison of ABTS, DPPH•, FRAP, and ORAC assays for estimating antioxidant activity from guava fruit extracts. J. Food Compost. Anal. 19(6-7), 669-675. DOI: 10.1016/j.jfca.2006.01.003.

48. Tournas, V. \& Katsoudas, E. (2005). Mould and yeast flora in fresh berries, grapes and citrus fruits. Int. J. Food Microbiol. 105, 11-17.

49. Ulbin-Figlewicz, N., Jarmoluk, A. \& Marycz, K. (2015). Antimicrobial activity of low-pressure plasma treatment against selected foodborne bacteria and meat microbiota. Ann. Microbiol. 65, 1537-1546. DOI: 10.1007/s13213-014-0992-y.

50. Valero, D., Martínez-Romero, D. \& Serrano, M. (2002). The role of polyamines in the improvement of the shelf life of fruit. Trends in Food Science \& Technology, 13(6-7), 228-234. https://doi.org/10.1016/S0924-2244(02)00134-6.

51. Valko, M., Rhodes, C., Moncol, J., Izakovic, M. M. \& Mazur, M. (2006). Free radicals, metals and antioxidants in oxidative stress-induced cancer. Chem. Biol. Interact. 160(1), 1-40. DOI: 10.1016/j.cbi.2005.12.009.

52. Wang, Z. (2013). Extraction process of polyphenols form wild Actinidia arguta in Dandong. J. Eas. Liaoning Univ.(Nat. Sci.), 1, 8-11.

53. White, A., de Silva, H. N., Requejo-Tapia, C. \& Harker, F. R. (2005). Evaluation of softening characteristics of fruit from 14 species of Actinidia. Postharvest Biology and Technology, 35(2), 143151. DOI: 10.1016/j.postharvbio.2004.08.004.

54. Wojdyło, A., Nowicka, P., Oszmiański, J. \& Golis, T. (2017). Phytochemical compounds and biological effects of Actinidia fruits. J. Funct. Foods. 30, 194-202. DOI: 10.1016/j.jff.2017.01.018.

55. Zhang, H., Zhao, Q., Lan, T., Geng, T., Gao, C., Yuan, Q., Zhang, Q., Xu., P, Sun, X., Liu, X. \& Ma, T. (2020). Comparative Analysis of Physicochemical Characteristics, Nutritional and Functional Components and Antioxidant Capacity of Fifteen Kiwifruit (Actinidia) Cultivars-Comparative Analysis of Fifteen Kiwifruit (Actinidia) Cultivars. Foods, 9(9), 1267. DOI: 10.3390/foods9091267.

56. Zhu, R., Feussner, K., Wu, T., Yan, F., Karlovsky, P. \& Zheng, X. (2015). Detoxification of mycotoxin patulin by the yeast Rhodosporidium paludigenum. Food Chem. 179, 1-5. DOI: 10.1016/j.foodchem.2015.01.066.

57. Zuo, L.L., Wang, Z.Y., Fan, Z.L., Tian, S.Q. \& Liu, J.R. (2012). Evaluation of antioxidant and antiproliferative properties of three Actinidia (Actinidia kolomikta, Actinidia arguta, Actinidia chinensis) extracts in vitro. Int. J. Mol. Sci. 13(5), 5506-5518. DOI: 10.3390/ijms13055506. 